\title{
An Analysis of Cultural Contents in English Textbook Used by the Eighth Grade Students of Junior High School 03 Bangkinang
}

\author{
Nurasia Andela \\ State Islamic University of Sultan Syarif Kasim Riau, Indonesia \\ nurasiaandela@gmail.com \\ M. Syafi'i S \\ State Islamic University of Sultan Syarif Kasim Riau, Indonesia \\ m.syafii.siec@gmail.com
}

\begin{abstract}
The title of this thesis is "An Analysis of Cultural contents in English Textbook used by the Eighth Grade Students of Junior High School 03 Bangkinang". This research was conducted based on some problems related to the cultural contents dissemination in the English Textbook. Absolutely, the objective of national education in Indonesia is set based on the cultural value and ideology of the nation. Thus, English textbook evaluation need to be conducted in order to know the appropriateness of the contents in the textbook. This research consisted of two formulations of the problem: how are the cultural contents disseminated in the English textbook entitled 'English in Focus for Grade VIII (SMP/MTs), and what are the cultural contents disseminated in the English textbook. The objectives of this research are to know about how the cultural contents are disseminated in the English textbook and what are the cultural contents disseminated in the English textbook. The data of the research were collected from reading passages and also pictures in the English Textbook which was published by National Education Department. This research is a descriptive qualitative but the element of quantitative in the form of how the data are counted in a percentage has also been used. In order to know what cultural contents are disseminated in the English Textbook, the cultural contents were categorized into the source or local culture, the target culture, and the international culture (Cortazzi \& Jin, 1999). Moreover, in order to know how the cultural contents were disseminated in the English Textbook, the cultural contents were categorized into four senses; the aesthetic sense, the sociological sense, the semantic sense, and the pragmatic sense (Adaskou, Britten \& Fahsi, 1990). The research found that local or source culture was predominant in the textbook. The cultural contents of $(43.75 \%)$ referred to the local culture, $(40.62 \%)$ referred to the international culture, and $(21.87 \%)$ referred to the target culture. Additionally, in order to know how the cultural contents are disseminated in textbook, the research found that generally the cultural contents were disseminated by the aesthetic sense
\end{abstract}


(46.15\%), the sociological sense $(30.76 \%)$, and the pragmatic sense (23.07\%), while the semantic sense was not found. Based on the findings, it could be concluded that the contents of English textbook in focus for grade VIII has already successfully achieved the national education goal. National characters or national culture should be input in education field.

\section{Keywords: Cultural contents, Four senses of culture, Types of culture, English Textbook.}

\section{Introduction}

The undividable components such as language and culture have become an interesting issue to be investigated in the field of English language teaching. Language is generally defined as a communication instrument in a social life; moreover, it also becomes a fundamental way of cultural transmission among people which come from different cultures and identities. In line with the ideas above, Byram and Peter (2003) stated that the existence of language becomes more beneficial and effective for the cultural development because it enables in promoting one's cultural issues including values, systems, norms, and such. Certainly, language itself is infected by the presence of culture because both culture and language are the two components which are closely related as said by Whorf (1956)as cited in Byram and Peter (2003).In addition, culture may be defined as a system of life created because of habit and communication; it is inherited from generation to generation. In other words, culture influences the way how people communicate, live, think, and behave. Thus, culture becomes a style of life designed by a particular group.
In terms of teaching-learning process, the EFL teachers have a big role for teaching the students in the classroom. The EFL teachers are expected to be able and active when delivering the materials to the students. In this case, the EFL teachers not only teach the materials to the learners but also observe and teach the cultural contents disseminated in English textbook.

In line with the idea above, according to Kramsch (2008) as cited in Liddicoat and Angela (1962) that in doing teaching, it is expected that the EFL teachers not only take their full concentration on the material being learned, but also consider the meaning or interpretation. In addition, Law of the Republic of Indonesia number 20 year 2003 in National Education System (Educational Law) formulates national education goal that should be used in developing education in Indonesia.

Article 3 of the Education Law states that national education goal is the formulation of the character must be developed in education. Character building can be delivered through education because national character which is a part of national culture. 
National culture is clearly stated as the basis of developing a curriculum.

In doing so, people should take a decision by selecting the textbook as a medium in teaching-learning process. Cunningsworth (1995) mentioned that the textbook is the best solution of any resource of teaching a new language and culture to the students. Textbook is believed having a big role and influence for students in both language learning, and cultural learning.

Regarding to the contents stated in the textbook, the materials in English textbook are containing cultural contents. According to McGrath (2002) in Hermawan \& Lia, (2012), language learning materials certainly contain the cultural contents.

Additionally, Cortazzi and Jin (1999) as cited in Chao (2011) review that the contents in the textbook are classified into several dimensions namely; target cultural materials which refer to the culture of native speakers, local cultural materials which refer to the culture of the country that its language is being learnt, and international cultural materials that refer to the culture besides local and target culture materials.

Additionally, according to Greene and Petty (1971) in Tarigan (1993), as cited in Rani Arba'ati (2015) that textbook must enable the students to be motivated and interested; the textbook must give the balance and the emphasis on the value of the students; and the textbook must be able to respect to the differences of the individual, and so forth.

In addition, Indonesian Board of National Education Standard (BSNP) has constructed some criteria for accredited English textbooks to be used at schools in Indonesia. BSNP developed some instruments of English textbook evaluation for every level of schools from primary schools (SD/MI) to high schools (SMA/MA). However, this instrument only touches some physical aspects of the English textbooks without analyzing the cultural contents appropriateness as one of the criteria of evaluation.

In Indonesia, the objective of national education is set based on the cultural value and ideology of the nation and applied in all school subjects including English. Considering textbooks which play important roles in English language teaching, thus, English textbooks evaluation needs to be conducted to make sure the appropriateness of the English textbook. The selection process of textbook in Indonesia has tendency or is not appropriate in term of cultural contents which exists because the reasons of choosing the textbook used may not consider the contents of the textbook.

Thus, the writer is interested in observing the problems above in to a research entitled "AN ANALYSIS OF CULTURAL CONTENTS IN ENGLISH TEXTBOOK USED BY THE EIGHTH GRADE STUDENTS OF JUNIOR HIGH SCHOOL 03 BANGKINANG"

\section{Research Methodology}

This research is a descriptive qualitative (content analysis). According to Gray et al, (2007), content analysis is exactly a set of process in examining the certain things especially in terms of art 
and literature (popular magazines, comics, television show, and any other literatures).

The goals of this research were to know about how the cultural contents are disseminated in English textbook and what the cultural contents are disseminated in English textbook. In doing so, McGrath (2002) proposed three methods for textbook evaluation; the impressionistic methods, the checklist method, and the in-depth method. Commonly, this research employed in depth method evaluation. In depth method evaluation examines the textbook in deeper and more detailed way by focusing on particular aspects such as kind of language description, underlying assumption about learning or values in which the materials are based, or the relevancy of materials to the context of textbook users (McGrath 2002).

For collecting data, the writer used such instrument namely documentation (English textbook entitled 'English in Focus for Grade VIII Junior High School (SMP/MTS)'. The data for this research are in form of reading passages and pictures since it contains the cultural values.

However, data analysis consists of two main stages. First, in order to know what cultural contents are disseminated in the textbook, the contents in the textbook including the reading passages and pictures which contain cultural values were categorized into the source culture, the target culture, and the international culture (Cortazzi and Jin, 1999). The source culture refers to Indonesian culture. The target culture refers to the culture of native speaker like UK and United States, and the international culture refers to cultures which do not belong to the source culture and the target culture.

Second, in order to know how the cultural contents are disseminated in the textbook, the cultural contents found in the textbook were categorized into the aesthetic sense, the sociological sense, the semantic sense, or the pragmatic sense (Adaskou, Britten\&Fahsi, 1990). Findings were then presented in the form of table and chart.

\section{Data Presentation and Discussion}

The findings related to cultural contents analysis of the English textbook are summarized and presented into two categories: what cultures are represented in the textbook based on the categorization proposed by Cortazzi and Jin (1999) and how the cultures are represented in the textbook based on the four senses of culture framework proposed by Adaskou, Britten, and Fahsi (1990). The result of the investigation is shown in the charts below.

Chart IV.1.

Cultural Contents Dissemination in the English Textbook

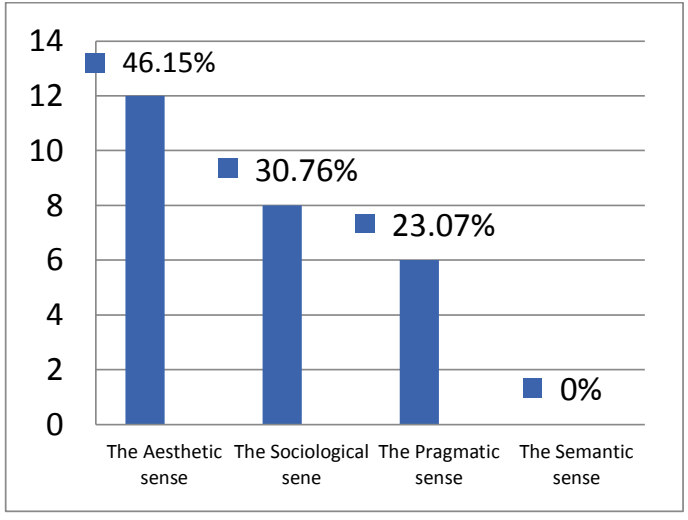




\section{How the Cultures are represented in the}

\section{Textbook.}

The cultural contents were categorized into the aesthetic sense, the sociological sense, the semantic sense, and the pragmatic sense (Adaskou, Britten $\&$ Fahsi, 1990) as well. The investigation found that cultures were represented in all senses of culture. The representations of culture were through various types of text describing literature, cinema, custom, stereotyping, food, etc.

Cultural contents in the textbook generally are represented by all senses of culture. The aesthetic sense was found predominant in representing culture in the textbook, followed by the sociological sense, the pragmatic sense, and the last was the semantic sense. The finding that cultures mostly are represented by the aesthetic sense.

Chart IV.2 Types of Cultural Contents

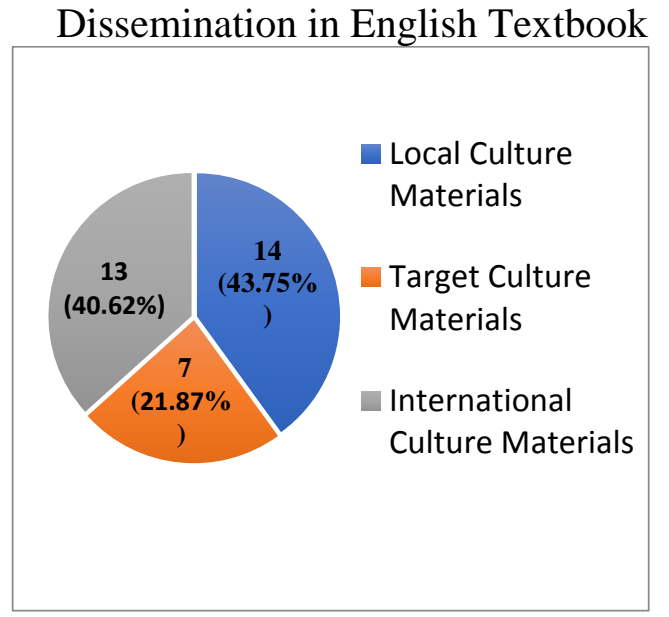

\section{What Cultures the Textbook Represents}

According to the data shown, the cultures represented in the textbook are the target culture, the source culture, and the international culture. According to the chart above, there was a comparison of frequency among the cultural categories. The source culture material was more predominant than target culture and international culture. The source culture was presented 14 times (43.75\%) in this textbook. Culture about Indonesia was disseminated in the form of both reading passages (Descriptive text) such as Bali, Nusa Tenggara, Bandung, Pangandaran in the West Java, Papua and Irian Jaya, and the picture such a Borobudur temple. Besides, the names of food like the word 'rujak' as the special food of Indonesia was to be considered.

In addition, the second dominant type of culture in this textbook was the international culture material which appeared 13 times (40.62\%). Culture about others countries was disseminated in form of names of cities such as; Egypt, Malaysia, Thailand, China, Italy, Netherlands, Singapore and such.

Meanwhile, the target culture material was less dominant in which the presentation appeared 7 times $(21.87 \%)$. Culture about the United States and UK was disseminated in the forms of names of buildings such as, Mount Rushmore in South Dakota, U.S.A, The White House in Washington D.C, and so forth. Besides, it was also presented the picture of well-known people like; Edward Jenner from England, Alexander Fleming from London, and so forth.

\section{Conclusion}

This article has presented the result of an analysis of cultural contents of an English textbook used by the eighth grade students of Junior High School 03 Bangkinang. The investigation of the textbook has revealed two major points; the source culture is predominantly represented in the textbook compared to the target culture and the international culture, and the culture in the 
textbook mostly is represented through the aesthetic sense.

In term of how cultures are represented in the textbook, the aesthetic sense ranks the top to representing culture in the textbook, followed by the sociological sense, the pragmatic sense, and the semantic sense.

Based on the findings, discussion, and the conclusion of this research, the writer offers a suggestion regarding the cultural contents in this textbook. The aesthetic sense of culture in the textbook is absolutely good because it can catch students' attention and interest. The sociological sense is also good because it can promote the learners how to live in different countries related to the family life, friendship life, and so forth. Then, the pragmatic sense such a language form is also effective for the students when they are learning English language which belongs to the native speaker. It would be better if the English Textbook author also include the semantic sense in the textbook. Thus, the students will know more about how students in different cultures perceive meaning from the learning.

\section{References}

Arba'ati, R. (2015). An analysis on English Textbook entitled Bahasa Ingrris "When English Rings a Bell" for the Eighth year Students of Junior High School based on the Curriculum 2013. Surakarta: Publication Article.

Byram, M \& Peter G. (2003). Context and Culture in Language Teaching and Learning. Clevedon: Multilingual Matters LTD.
Cunningsworth, A. (1995). Choosing your Coursebook. New York: Macmillan.

Hermawan, B, \& Lia N. (2012). Traces and Cultures in English Textbooks for primary Education. Indonesian Journal of Applied Linguistics, 4952.

Liddicoat, A. J, \& Angela S. (2013). Intercultural Language Teaching and Learning.Washignton D.C: Willey- Blackwel.

Nasional, K. P. (2010). Pengembangan Pendidikan Budaya dan karakter Bangsa. Jakarta: Kementrian Pendidikan Nasional.

Syafi'i M. (2014). From Paragraph to a Research Report: A Writing of English for Academic Purposes. Pekanbaru: Suska Press.

Xiao, J. (2010). Cultural Contents of an in-use EFL Textbook and English

Major Studemts' Attitudes and Perceptions towards Culture Learning at Jiangxi University of Science and Technology, China : Prince of Songkla Univers.

Zajda, J, \& Kassie, F. (2009). Race, ethnicity, and Gender in Education: Cross Cultural Understanding. Washington D.C: Springer. Little, Brown and 
Nurasia Andela, M. Syafi'i S - An Analysis of Cultural Contents In English Textbook ...

Company. Boston Toronto

Badan Standar Nasional Pendidikan

(BSNP). (2011). Instrumen

Penilaian Buku Teks Bahasa

Inggris Tingkat SMP/MTs Tahun

2011. Download fromhttp://bsnp indonesia.org/id?p=734

Nasional, K.P (2010). Pengembangan Pendidikan Budaya dan Karakter Bangsa. Jakarta: Kementrian Pendidikan Nasional.

McGrath. I. (2010). Materials Evaluation and Design for Language Teaching. Endiburgh: Endiburgh University Press.

Gray, P. S et al. (2007). The Research Imagination . Washigton D.C: Cambridge University press.

Hermawan, B, \& Lia N. (2012). Traces and Cultures in English Textbooks for primary Education. Indonesian Journal of Applied Linguistics, 4952

Chao, T. (2011). The Hidden Curriculum of cultural content in internationlly published ETL textbooks: A closer look at new American inside out. The Journal of Asia TEFL 8(2), 189-210. 